\title{
УКРАЇНСЬКИЙ РИНОК ПРАЦІ В УМОВАХ COVID-19 ТА ОБЛІКОВІ АСПЕКТИ ОПЛАТИ ПРАЦІ
}

\begin{abstract}
Анотація. В статті розглянуто вплив пандемії COVID-19 на український ринок праці. Проаналізовано кількість безробітного та зайнятого населення й динаміку оплати праці у 2018-2020 рр. Визначено сфрери, які найбільше піддалися негативному впливу пандемії COVID-19. Охарактеризовано умови оплати праці під час простою та особливості кожного варіанту організації роботи в умовах карантину. Розглянуто шляхи уникнення скорочення штату працівників й відповідальність за порушення даного питання. Досліджено зміни оподаткування заробітної плати та аналіз трансформащї законодавчої бази, пов’язаної 3 темою дослідження. Висвітлені заходи, які прийняті урядом задля підтримки роботодавців та працівників, які втратили доходи для зменшення негативних наслідків пандемії. Визначено шляхи покращення обліку оплати праці в умовах карантинних обмежень.
\end{abstract}

Ключові слова: оплата праці, організація бухгалтерського обліку, COVID-19, виплата заробітної плати, оподаткування, ринок праці.

Shot Anna, Mosolova Yuliia

Lviv National University of Ivan Franko

\section{UKRAINIAN JOB MARKET DURING COVID-19 EPIDEMIC AND ACCOUNTING ASPECTS OF PAYROLL DATA}

Summary. The effective functioning of the labour market in Ukraine depends, first of all, on the social and economic situation in the country, structural changes in the wourld and national economies are influencing. In this article the impact of the COVID-19 pandemic on the Ukrainian labor market considered. In the article the economic and social conditions of calculation of wages, determined by the current legislation of Ukraine are considered. In the market economy environment the labour market should: provide the working population with the income which meets their social and economic needs; reduce social inequality in society and ensure social and economic stability; make the most of the country's labour potential.The number of unemployed and employed population and the dynamics of wages in 2018-2020 have analyzed. The areas most affected by the COVID-19 pandemic have been identified. Conditions of payment during downtime and features of each variant of the organization of work in the conditions of quarantine are characterized. Recent changes in legislation concerning wages accounting are analyzed. Ways to avoid staff reductions and liability for violating this issue are considered. Changes in wage taxation and analysis of the transformation of the legal framework related to the research topic have been studied. With reliable and complete information, the accountant will be able to efficiently keep a record of wages without violating the law. The measures taken by the government to support employers and workers who have lost income to reduce the negative effects of the pandemic are highlighted. Overview of recent legislative changes in Ukraine in respect to taxation of employee benefits is done. Improvement of quality of accounting information owing to unequivocal understanding of legislative changes is established. The definition of systems and forms of remuneration. Ways to improve payroll accounting under quarantine restrictions have been identified. Research result has theoretical and practical significance in reflecting employee benefits, taxes on accounts.

Keywords: remuneration, organization of accounting, COVID-19, payment of wages, taxation, labour market.

$\Pi$ остановка проблеми. Негативний вплив пандемії коронавірусу COVID-19 на світову, в тому числі і українську економіку є суттевим, найбільшого ж зазнали ринки праці. В процесі дослідження ринків праці є важливим розглянути зміну оплати праці із запровадженням карантину.

Облік оплати праці є одним з найважливіших і складних ділянок роботи, що займае одне з центральних місць у всій системі обліку на підприемстві, оскільки потребують точних і оперативних даних, у яких відбиваеться зміна чисельності робітників, витрати робочого часу, категорії робітників.

Заробітна плата е одним із основних доходів громадян нашої країни. У зв'язку із пандемією COVID-19 та введенням карантину значна кількість діючих суб'єктів господарювання, окрім об’ектів критичної інфраструктури, вимушена була обмежити чи призупинити господарську діяльність, відповідно і питання оплати праці набуло ще більшої актуальності. Разом з тим система оподаткування заробітної плати зазнала численних трансформацій та перетворень, оскільки задля підтримки бізнесу уряд зменшив податкове навантаження.

Вищезгадані питання обов'язково потребують внесення змін до законодавства, пов'язаного з темою дослідження, адже дотримання законів в пріоритеті, оскільки за їх порушення передбачена адміністративна та в деяких випадках кримінальна відповідальність.

Аналіз останніх досліджень і публікацій. Проблематика обліку, організації оплати праці, ринку праці висвітлені у наукових працях Ткаченко Н.М., Бутинця Ф.Ф., Лишиленко О.В., Сопко В.В., Усача Б.Ф., Макаренко А.П., Меліхова Т.О. та інші.

Проте питання ринку праці та оплати праці в умовах COVID-19 є новим, актуальним і потребуе дослідження. 
Метою статті $є$ провести аналіз впливу пандемії COVID-19 на український ринок праці та дослідження варіантів організації оплати праці в умовах карантинних обмежень.

Виклад основного матеріалу дослідження. Пандемія COVID-19 вплинула як на світову, так і на українську економіку, що призвело до змін на вітчизняному ринку праці, зокрема:

- фактичного скорочення рівня зайнятості;

- зростання кількості безробітних;

- зменшення кількості трудових мігрантів;

- зменшення доходів населення України, внаслідок зменшення заробітної плати або ж втрати роботи.

Для оцінки масштабів впливу пандемії саме на оплату праці, потрібно насамперед розглянути поняття заробітної плати. Заробітну плату згідно зі ст. 1 Закону України «Про оплату праці» визначають як «винагороду обчислену, як правило, у грошовому виразі, яку за трудовим договором роботодавець виплачуе працівникові за виконану ним роботу. Розмір заробітної плати залежить від складності та умов виконуваної роботи, професійно-ділових якостей працівника, результатів його пращі та господарської діяльності підприемства» [1].

Заробітна плата є основним доходом населення України, а оскільки велика кількість працівників втратили роботу внаслідок пандемії коронавірусу, то кількість безробітних у нашій країни значно зросла. Відповідно розглядаючи аспекти оплати праці в умовах COVID-19, потрібно насамперед дослідити зміни у ринку праці.
За даними Торгово-промислової палати, на сьогодні в Україні призупинило свою діяльність близько 700 тисяч підприемств, установ та організацій, що забезпечували роботою понад 3,5 млн людей.

Кількість зареестрованих безробітних за видами економічної діяльності в Україні подано на рис. 1.

3 рис. 1. видно, що кількість безробітних у відповідний період 2020 р. порівняно 32019 р. зросла у всіх сферах економічної діяльності. Найбільшого впливу зазнала сфера торгівлі та ремонту, де кількість пращівників, які втратили роботу зросла удвічі, в свою чергу найменшого впливу зазнала сфера постачання електроенергії. Важливим $е$ те, що у сфері державного управління та оборони кількість безробітних зменшилася, що є позитивним явищем.

Задля детальнішого розуміння, як зросла кількість безробітних саме у період карантину, пов'язаного з пандеміею коронавірусу, розглянемо зміни по місяцях 2019-2020 pp. (рис. 2).

Аналізуючи кількість безробітного населення, доцільного розглянути кількість зайнятого населення у аналогічний період (рис. 3).

3 рис. 2 та 3 видно, що відразу із запровадженням карантину значна кількість працівників втратили роботу і доходи.

Для зменшення негативних наслідків Уряд прийняв низку заходів щодо підтримки такої категорії населення та бізнесу. Більшість з яких стосуються бізнесу у сорері торгівлі та послуг (рис. 4).

Відповідно до розрахунків інвестиційної компанії «Dragon Capital», «кількість безробітних

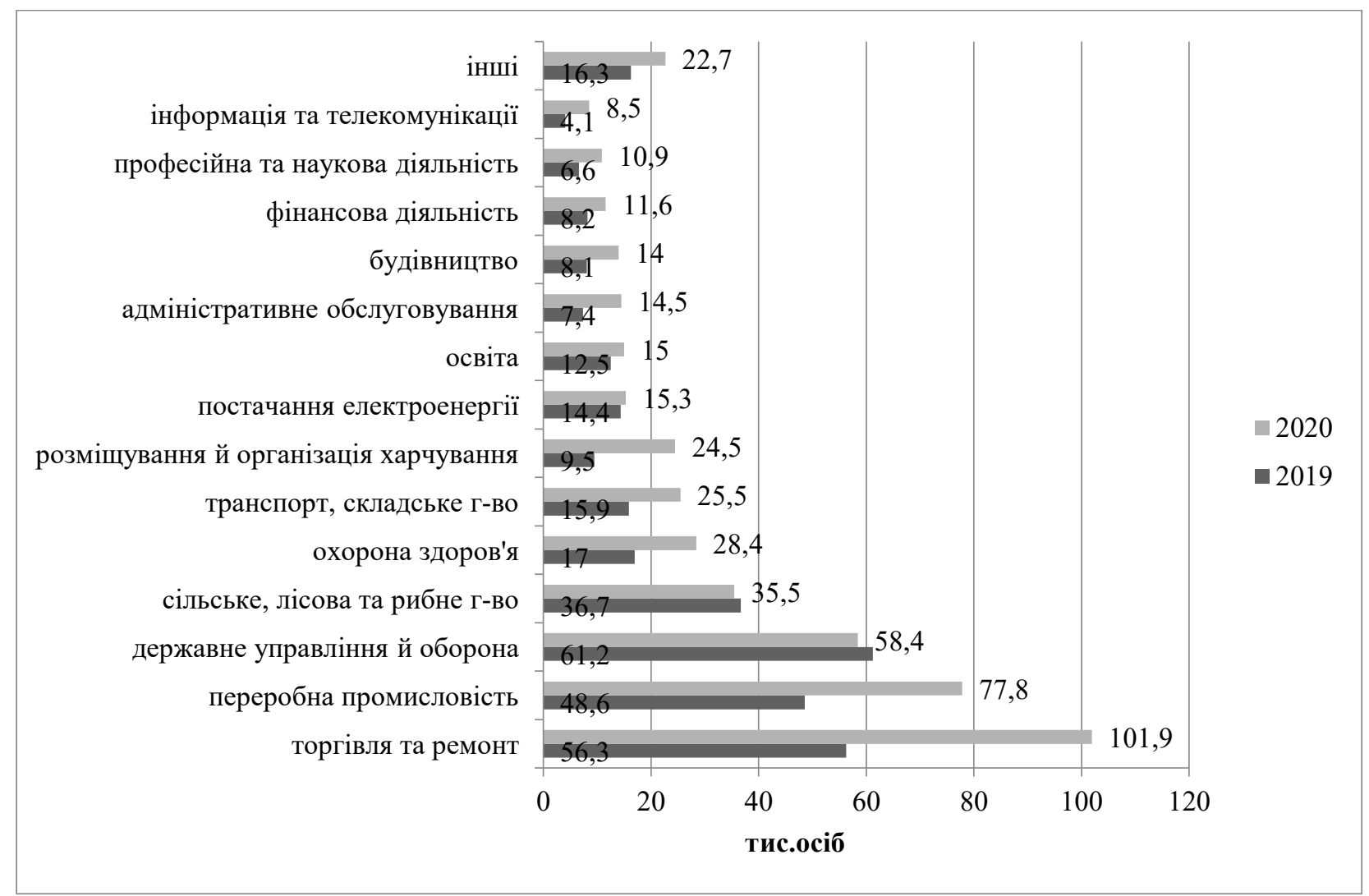

Рис. 1. Кількість зареестрованих безробітних в Україні за видами економічної діяльності з 12 березня по 31 жовтня 2019-2020 рр., тис. осіб 


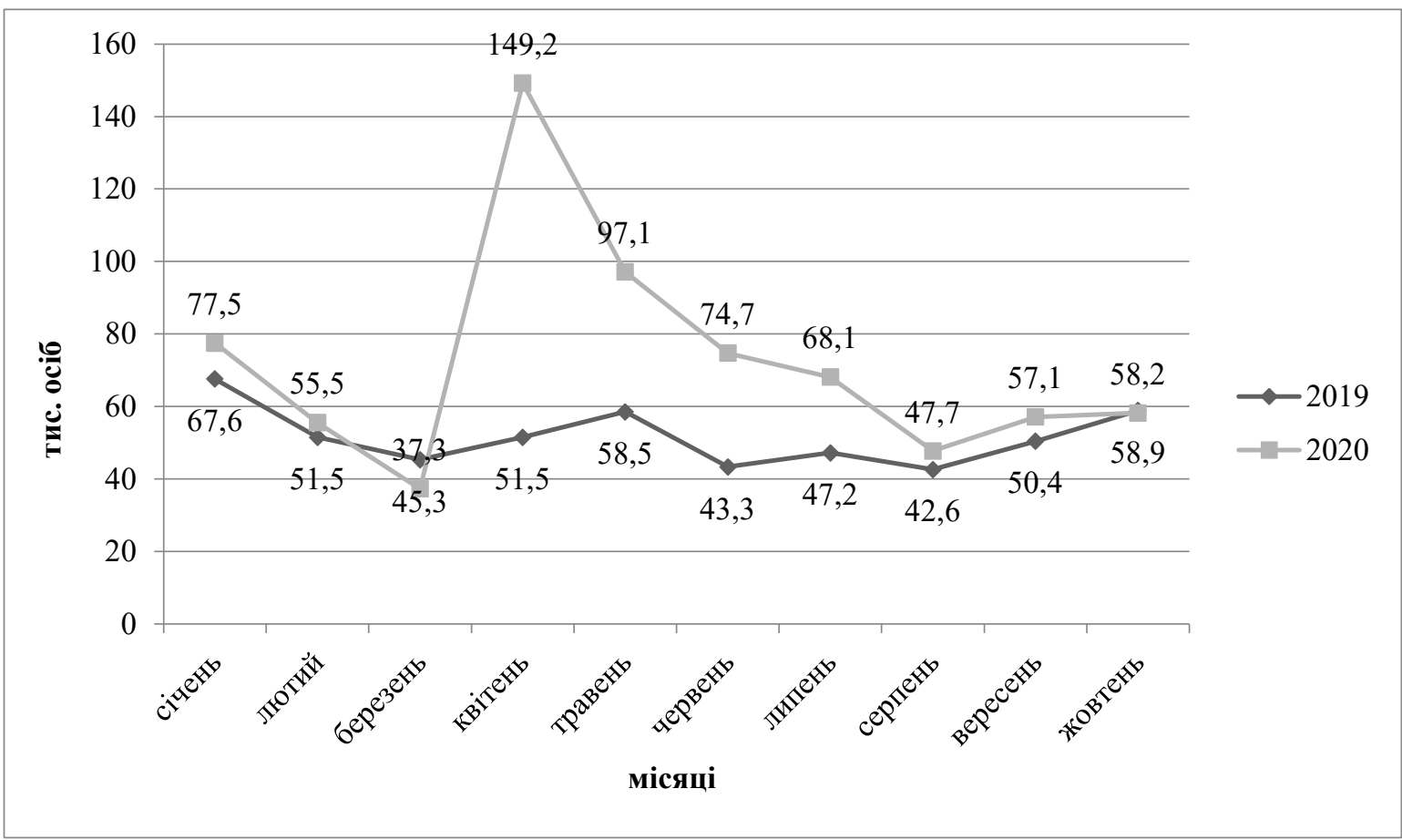

Рис. 2. Кількість заресстрованих безробітних у 2019-2020 рр., тис. осіб Джерело: побудовано авторами на основі [11]

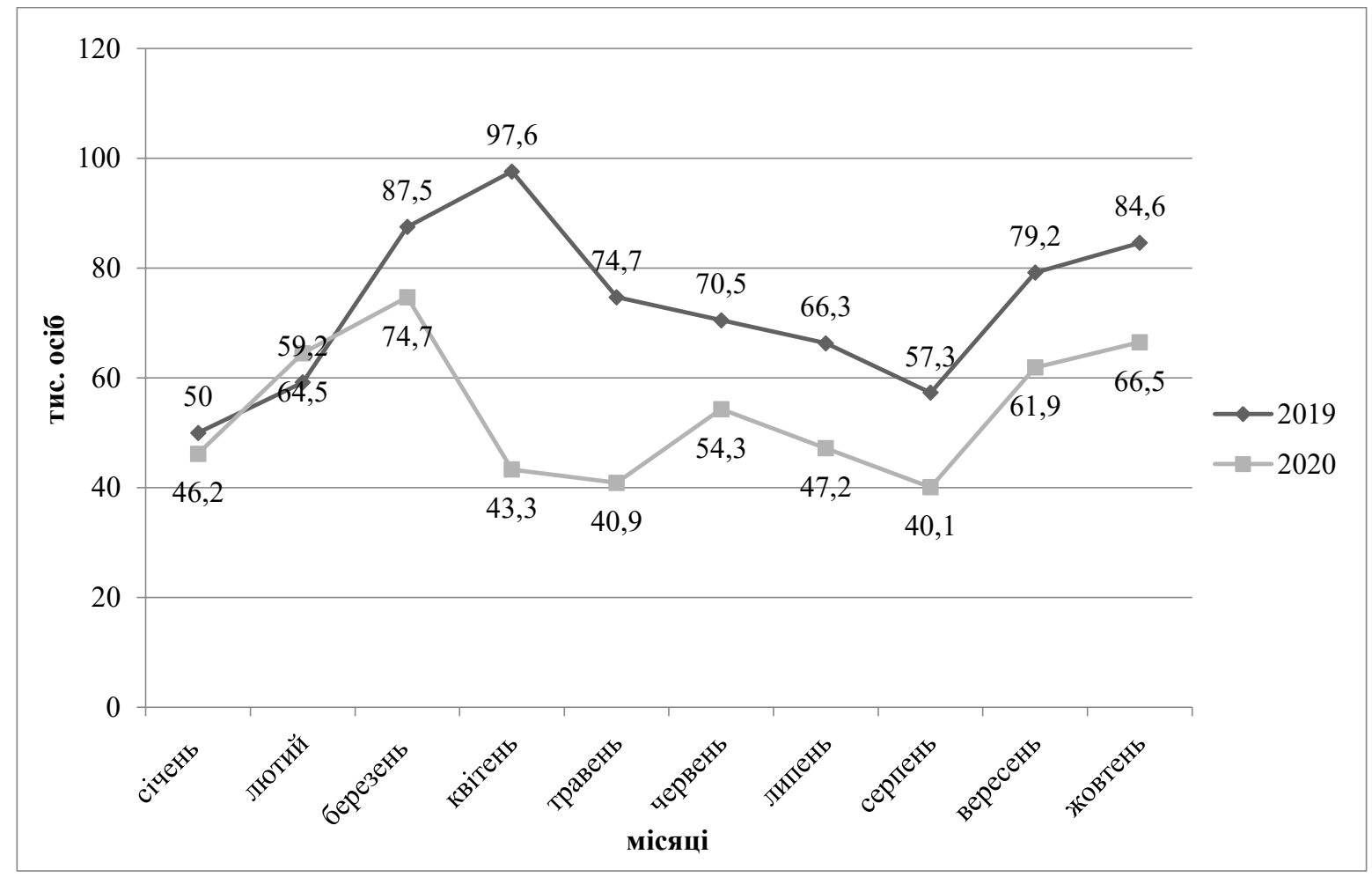

Рис. 3. Кількість працевлаштованих осіб у 2019-2020 рр., тис. осіб

Джерело: побудовано авторами на основі [11]

в Україні, за підсумками квітня 2020 р., зросла приблизно з 9 до 20\%. Тобто, із 17 млн робочих місць, що включають і тіньову економіку, 3,4 млн підуть у нікуди» [2]. Уряд публічно представив оцінку, згідно з якою, у 2020 р. безробіття в Україні зросте до 9,4\%, при тому що в 2019 р. даний показник становив 8,2 \% [3].
Проведені дослідження показників Держкомстату України показали, що рівень безробіття населення України віком від 15 до 70 років у період з I кварталу 2016 р. до I кварталу 2020 р. включно коливався в межах від 7,3 до 10,1\%. Із запровадженням карантинних обмежень в Україні у I кварталі 2020 р. рівень безробіття становив 8,6\% [4]. 


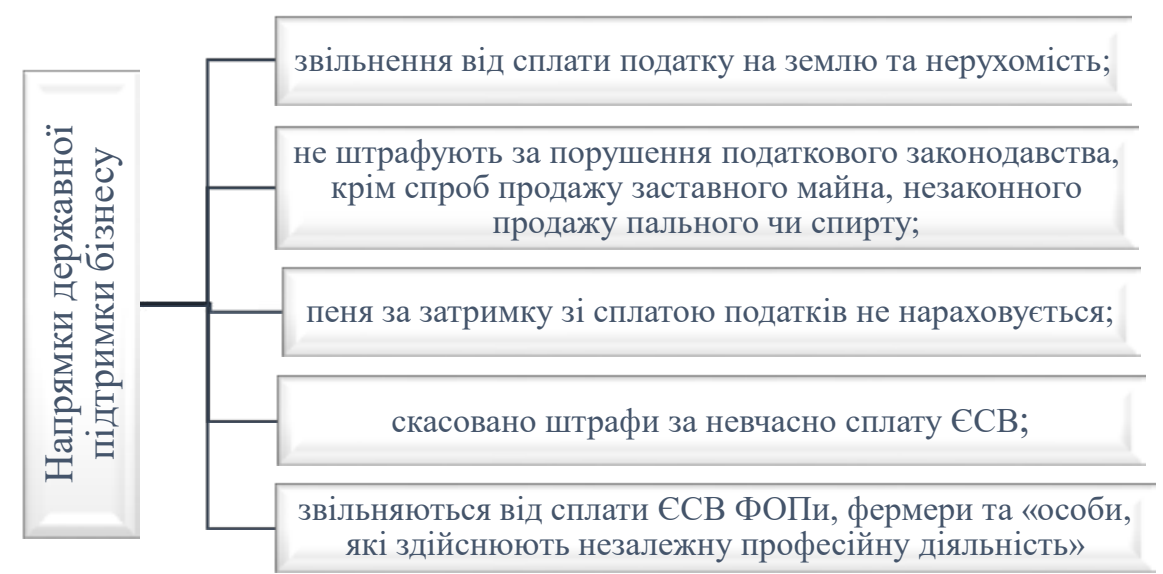

Рис. 4. Напрямки державної підтримки окремих категорій населення та бізнесу

Джерело: власна розробка

В макроекономічний та монетарний аналіз свідчить, що через падіння сукупного попиту потреба в робочій силі у травні - червні 2020 р. залишалася нижчою, ніж до карантину. Натомість пропозиція робочої сили повністю відновилася на тлі відновлення роботи транспорту й пом'якшення карантину. Зазначені зміни потреби в робочій силі знайшли своє відображення в динаміці оплати праці. Сповільнення спаду у базових галузях у травні 2020 р. сприяло зростанню зарплати (на $3,0 \%$ рік до року $(\mathrm{p} / \mathrm{p})$ у номінальному та $1,4 \% \mathrm{p} / \mathrm{p}$ у реальному вимірі). Також підтримку зарплатам надавали надбавки медичним працівникам, що працюють з хворими на COVID-19. Водночас зростання пенсійних виплат залишалося значним через індексацію пенсій у травні [5]. На рис. 5 подано динаміку середньої заробітної плати та пенсійних виплат протягом 2018-2020 pр.

Слід зазначити, що попри загальне поліпшення ситуації із зарплатами найманих працівників в українській економіці в цілому, у ряді галузей ситуація із зарплатами була доволі складною. Насамперед це стосуеться готельно-ресторанного бізнесу. Також карантин негативно вплинув на будівництво, оскільки були проблеми із доставкою працівників на об'єкти будівництва. Це пов'язано 3 тим, що через запровадження карантинних обмежень була припинена робота транспорту (рис. 6).

Суб’екти господарювання, які призупинили свою діяльність через пандемію коронавірусу, вважаються такими, що перебувають у стані простою. Простій - це призупинення роботи, викликане відсутністю організаційних або технічних умов, необхідних для виконання роботи, невідворотною силою або іншими обставинами [7]. По суті працівник перебуває в трудових відносинах 3 підприемством та відповідно час простою оплачуеться у сумі не нижче від двох третин тарифної ставки встановленого працівникові розряду (окладу).

Водночас, під час простою не здійснюеться виплата доплат і надбавок, передбачених колективним договором, адже робітники під час простою не виконують встановлену їм норму праці. Проте, ті виплати, які є обов'язковими та напряму прив'язані до окладу зберігаються, серед них: доплати за ступінь, стаж, звання тощо, якщо ж такі є.

Необхідно відмітити, що роботодавці на період карантину у зв'язку з COVID-19 також можуть:

- запровадити віддалену (дистанційну) роботу для працівників;

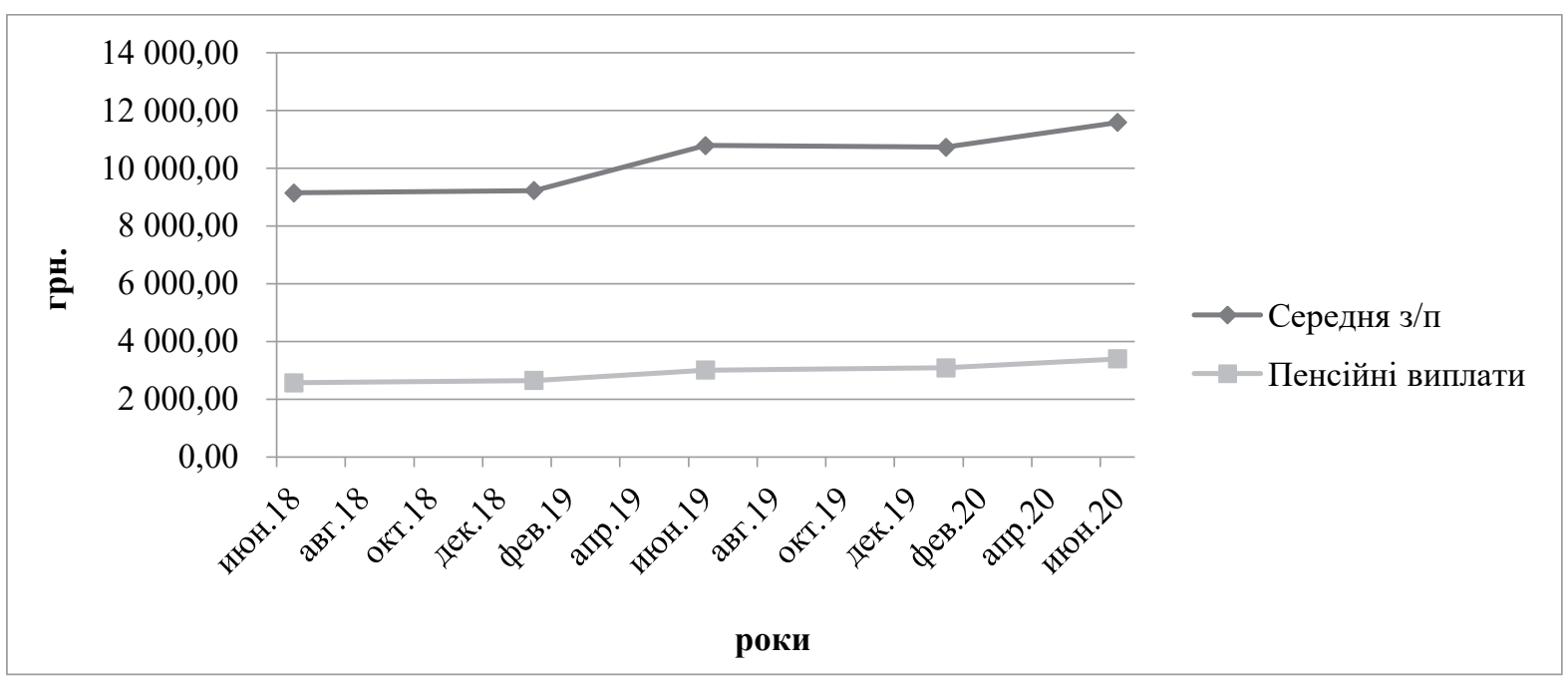

Рис. 5. Динаміка середньої заробітної плати та пенсійних виплат за 2018-2020 рр. 


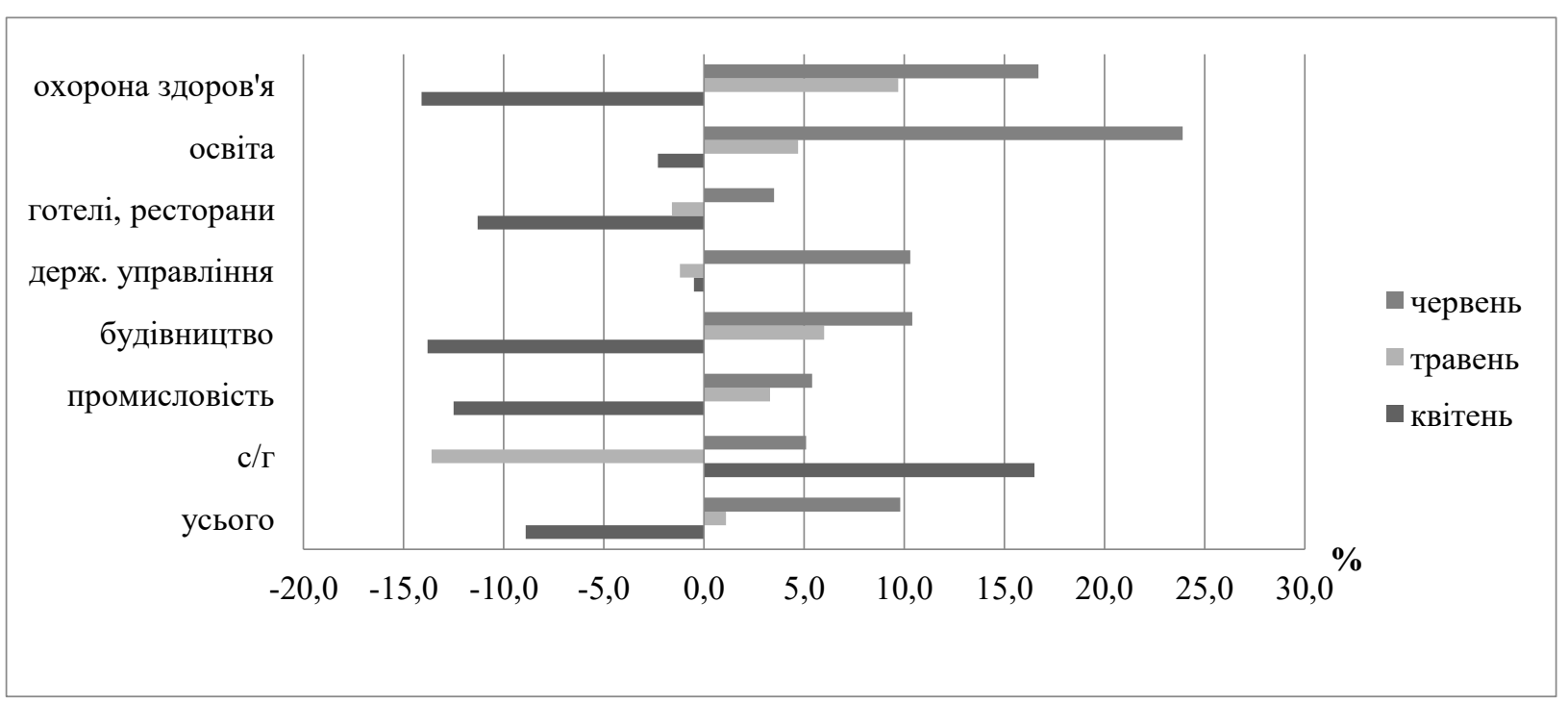

Рис. 6. Заробітна плата за видами діяльності за квітень-травень 2020 р., \% p/p

Джерело: побудовано авторами на основі [4]

- надати працівникам відпустки, зокрема, без збереження заробітної плати за згодою сторін.

У разі, коли працівники виконують доведені їм завдання у віддаленому режимі та звітують про виконану роботу щодня оплата праці залишається на рівні з оплатою праці, яка нараховувалась пращівнику до запровадження дистанційного режиму роботи. Але роботодавцю необхідно внести зміни до правил внутрішнього трудового розпорядку щодо віддаленої форми роботи.

Таким чином, не вникаючи в особливості може здатися, що виконання працівником роботи вдома $є$ чудовою альтернативою роботи на час карантину, проте є суттевий недолік даного режиму роботи, а саме те, що відправити виконувати роботу вдома можна далеко не усіх робітників.

Важливим є те, що парламентом прийнято за основу проект Закону «Про внесення змін до деяких законодавчих актів щодо удосконалення правового регулювання дистанційної роботи», передусім задля розмежування дистанційної та надомної праці. Відповідно до законопроекту, дистанційна робота трактуеться як робота, що виконуеться працівником поза приміщеннями роботодавця в будь-якому місці за його вибором й 3 використанням інформаційно-комунікаційних технологій. А власне надомна робота - це коли робота виконуеться за місцем його проживання працівника або в інших заздалегідь обраних ним приміщеннях, які характеризуються наявністю закріпленої зони, технічних засобів або їх сукупності.

Задля уникнення скорочення штату чи чисельності працівників, роботодавець може запропонувати працівникам скористатися правом на відпустки. Дана альтернативна є також вигідною для працівника, з огляду на те, що на момент перебування працівника у відпустці за ним зберігається робоче місце і відповідно ризик звільнення е мінімальним.

Кожен пращівник відповідно до чинного законодавства на весь період карантину чи на якусь його частину, має право взяти такі види відпустки:
- щорічну відпустку зі збереженням заробітної плати;

- відпустку на період карантину без збереження заробітної плати;

- відпустку без збереження заробітної плати тривалістю до 15 днів;

- відпустку без збереження заробітної плати (або із частковим збереженням) для догляду за дитиною до досягнення нею трирічного віку;

- відпустку без збереження заробітної плати для догляду за дитиною віком до 14 років;

- додаткову відпустку для працівників, які мають дітей або повнолітню дитину - особу 3 інвалідністю 3 дитинства та/або жінок, які мають двох або більше дітей віком до 15 років;

- а також інших відпусток, які передбачені Законом України «Про відпустки».

Щодо відправлення у відпустку за власним бажанням, то необхідно зазначити, що керівник не може відправити усіх працівників у відпустки, так як передусім це порушенням трудового законодавства і відповідно за це передбачено адміністративну відповідальність у сумі до 1700 грн., а в деяких випадках й кримінальну відповідальність.

Роботодавцям слід врахувати, що 30 березня 2020 року Верховна Рада України прийняла Закон України «Про внесення змін до деяких законодавчих актів України, спрямованих на запобігання виникненню і поширенню коронавірусної хвороби (COVID-19)». За порушення трудового законодавства роботодавці можуть бути притягнені до таких видів відповідальності: дисциплінарної, матеріальної, адміністративної, фрінансової та кримінальної. При цьому такі види відповідальності будуть застосовуватися незалежно один від одного. Посадові особи можуть бути притягнені до адміністративної та кримінальної відповідальності на підставі результатів перевірки Держпраці.

3 метою мінімізацї витрат на персонал недобросовісні роботодавці вдаються до таких дій:

- ухилення від офіційного укладення трудового договору з працівниками; 
- примусове відправлення працівників у відпустку без збереження заробітної плати;

- встановлення неповного робочого дня при фактичному залученні до роботи працівників на повний робочий день;

- часткова виплата нарахованої заробітної плати неофіційно без сплати податку та єдиного соціального внеску;

- продовження тривалості робочого часу без офріційного залучення працівників до надурочних робіт та оплати надурочної роботи.

Крім цього, доречно розглянути питання звільнення працівників із запровадженням карантинних обмежень в Україні. Згідно з трудовим законодавством, запровадження карантину не $є$ самостійною правовою підставою для звільнення працівника 3 ініціативи роботодавця. Проте він може розглядатися як передумова для проведення роботодавцем процесу скорочення чисельності або штату працівників. Але у такому випадку роботодавец повинен вжити обов'язкових заходів, які зазвичай застосовуються у даній ситуації.

В той же час слід пам'ятати, що працівник може бути звільнений з посади виключно у разі наявності змін в організації виробництва і праці роботодавця.

Також важливим питанням постало оподаткування доходів працівників під час карантину. У зв'язку з відсутністю бази нарахування платники податків мали змогу не сплачувати ПДФО, В3 та ССВ, оскільки заробітної плати (та інших доходів) у певного працівника протягом місяця не було. Не виконується в цьому випадку і вимога у нарахуванні ССB в розмірі мінімального страхового внеску. У разі, нарахування доходів працівнику, звільнення зарплати (лікарняних, відпускних) на час карантину від ПДФО, ВЗ та ССВ не сталося.

Тому, при їх нарахуванні слід нараховувати і ПДФО, ВЗ та ССВ. І сплатити ці платежі треба у строки, встановлені законодавством. Як правило, це день виплати такого доходу працівнику. А якщо він був нарахований, але не був виплачений, то діють граничні строки сплати:

- для ПДФО та ВЗ - це 30 днів місяця, наступного за місяцем, у якому дохід було нараховано;

- для $\mathrm{CB}$ - це 20 число (і тільки для гірничих підприемств - 28 число) місяця, наступного за місяцем, у якому дохід було нараховано.

Варто зазначити, що за порушення податкового законодавства в період карантину штрафи не стягуються й платникам податків не нараховується пеня, а нарахована, але не сплачена за цей період пеня, підлягає списанню.

Задля підтримки бізнесу, на період карантину, пов'язаного $з$ коронавірусною інфекцією було звільнено від нарахування та сплати ССВ таких груп осіб:

- фрізичні особи-підприемці, в тому числі ті, які обрали спрощену систему оподаткування;

- особи, які провадять незалежну професійну діяльність;

- члени фрермерського господарства, якщо вони не належать до осіб, які підлягають страхуванню на інших підставах.
При цьому, зазначені особи можуть самостійно прийняти рішення про сплату єдиного внеску за вказані періоди у розмірах та порядку, визначених законодавством та відобразити це у звітності. Слід також звернути увагу, що ФОП першої та другої групи (без працівників) може зекономити на податках, адже має можливість піти у відпустку на один календарний місяць.

У разі запровадження жорсткіших обмежень в Україні, а саме запроваджено локдаун вихідного дня роботодавцям необхідно врахувати наступне:

- Переважно субота і неділя - вихідні дні, але у деяких сорерах діяльності це основні робочі дні, від яких отримують найбільше доходів. Тому для великої кількості працівників даних видів діяльності субота і неділя є робочими днями.

- Для того, щоб такі категорії працівників могли працювати у вихідні дні, потрібно встановити для них підсумований режим робочого часу або ж інші вихідні, проте необхідно пам'ятати про те, що дані працівники не мають обслуговувати відвідувачів.

- Крім цього, є категорія працівників, які взагалі не мають права працювати в суботу та неділю, щодо них є декілька варіантів вирішення ситуації: відправити у відпустку на вихідні, встановити простій, призупинити або скоротити діяльність, змінити графік роботи або ж встановити неповний робочий час.

Найкращим варіантом на нашу думку є, встановлення підсумованого обліку робочого часу. Проте, це допускається лише за умови, що тривалість робочого часу за графіками роботи не перевищуе норми тривалості робочого часу. У разі переробітку працівникам зазвичай надають інші дні відпочинку чи в кінці облікового періоду оплачують години надурочної роботи у підвищеному розмірі.

Висновки 3 даного дослідження i перспективи. За результатами проведеного дослідження можна стверджувати, що сьогодні бізнес та суспільство стали заручниками ситуації, яка диктуе свої правила. Український ринок праці під впливом пандемії зазнав суттевих змін. На даному етапі, можна стверджувати, що сьогодні він частково оживає. Запровадження на території України карантину та розповсюдження коронавірусу COVID-19 не слід розглядати як підставу для допущення порушення вимог трудового законодавства, у тому числі прав осіб на працю та отримання заробітної плати. В свою чергу, Уряд запроваджує механізми, спрямовані на захист працівників та роботодавців.

Резюмуючи викладене, вважаємо, що держава через систему державних органів у симбіозі 3 бізнесом та суспільством мають усі шанси на подолання наслідків карантину та розповсюдження коронавірусу COVID-19, не допускаючи понесення значних втрат.

Подальші дослідження за даною проблематикою можуть бути спрямовані на розв'язання проблеми наповнення Державного бюджету у зв'язку із скороченням податкових надходжень під час пандеміі, вирішення проблеми зайнятості тощо. 


\section{Список літератури:}

1. Про оплату праці : Закон України від 24.03.1995 № 108/95-ВР. Відомості Верховної Ради України (ВВР), 1995, № 17, ст. 121.

2. Центр досліджень соціальних комунікацій. URL: https://nv.ua/ukr/biz/economics/bezrobittya-v-ukrajini-skilkiukrajinciv-vtratili-robotu-cherez-karantin-novini-ukrajini-50085855.html

3. Інформаційно-аналітичний журнал «Україна: події, фракти, коментарі». URL: https://nv.ua/ukr/biz/economics/ bezrobittya-v-ukrajini-shmigal-rozpoviv-naskilki-zrosla-kilkist-bezrobitnih-novini-ukrajini-50093649.html

4. Державна служба статистики України. URL: http://www.ukrstat.gov.ua/

5. Макроекономічний та монетарний огляді. Червень 2020 року. НБУ. URL: https://bank.gov.ua/admin_uploads/ article/MM_2020-06.pdf?v=4

6. Пенсійний фонд України. URL: https://portal.pfu.gov.ua/

7. Кодекс законів про працю України. Кодекс від 10.12.1971 № 322-VIII. Затверджуеться Законом № 322-VIII від 10.12.1971 ВВР, 1971, додаток до № 50, ст. 37.

8. Кодекс про адміністративні правопорушення від 07.12.1984 № 8073-Х. Відомості Верховної Ради Української РСР (ВВР) 1984, додаток до № 51, ст. 1122.

9. Трудові відносини під час коронавірусу. URL: https://pravo.ua/trudovi-vidnosini-pid-chas-koronavirusu/

10. COVID-19: організація дистанційної роботи та оплати праці під час карантин. URL: http://www.visnuk.com.ua/ uk/news/100017192-covid-19-organizatsiya-distantsiynoyi-roboti-ta-oplati-pratsi-pid-chas-karantin

11. Державна служба зайнятості. URL: https://www.dcz.gov.ua/

\section{References:}

1. Pro oplatu pratsi: Zakon Ukrainy vid 24.03.1995 № 108/95-VR. Vidomosti Verkhovnoi Rady Ukrainy (VVR), 1995, № 17 , st.121.

2. Tsentr doslidzhen sotsialnykh komunikatsii. URL: https://nv.ua/ukr/biz/economics/bezrobittya-v-ukrajini-skilkiukrajinciv-vtratili-robotu-cherez-karantin-novini-ukrajini-50085855.html

3. Informatsiino-analitychnyi zhurnal «Ukraina: podii, fakty, komentari». URL: https://nv.ua/ukr/biz/economics/ bezrobittya-v-ukrajini-shmigal-rozpoviv-naskilki-zrosla-kilkist-bezrobitnih-novini-ukrajini-50093649.html

4. Derzhavna sluzhba statystyky Ukrainy. URL: http://www.ukrstat.gov.ua/

5. Makroekonomichnyi ta monetarnyi ohliadi. Cherven 2020 roku. NBU. URL: https://bank.gov.ua/admin_uploads/ article/MM_2020-06.pdf?v=4

6. Pensiinyi fond Ukrainy. URL: https://portal.pfu.gov.ua/

7. Kodeks zakoniv pro pratsiu Ukrainy. Kodeks vid 10.12.1971 № 322-VIII. Zatverdzhuietsia Zakonom № 322-VIII vid 10.12.1971 VVR, 1971, dodatok do № 50, st. 37.

8. Kodeks pro administratyvni pravoporushennia vid 07.12.1984 № 8073-X. Vidomosti Verkhovnoi Rady Ukrainskoi RSR (VVR) 1984, dodatok do № 51, st.1122.

9. Trudovi vidnosyny pid chas koronavirusu. URL: https://pravo.ua/trudovi-vidnosini-pid-chas-koronavirusu/

10. COVID-19: orhanizatsiia dystantsiinoi roboty ta oplaty pratsi pid chas karantyn. URL: http://www.visnuk.com.ua/ uk/news/100017192-covid-19-organizatsiya-distantsiynoyi-roboti-ta-oplati-pratsi-pid-chas-karantin

11. Derzhavna sluzhba zainiatosti. URL: https://www.dcz.gov.ua/ 